\title{
Cyanobacteria Growth in Nitrogen- \& Phosphorus-Spiked Water from a Hypereutrophic Reservoir in Kentucky, USA
}

\author{
Sarah E. Hughes, Jason W. Marion* \\ Department of Environmental Health Science, College of Health Sciences, Eastern Kentucky University, \\ Richmond, KY, USA \\ Email: *jason.marion@eku.edu
}

How to cite this paper: Hughes, S.E. and Marion, J.W. (2021) Cyanobacteria Growth in Nitrogen- \& Phosphorus-Spiked Water from a Hypereutrophic Reservoir in Kentucky, USA. Journal of Environmental Protection, 12, 75-89.

https://doi.org/10.4236/jep.2021.122006

Received: January 19, 2021

Accepted: February 20, 2021

Published: February 23, 2021

Copyright $\odot 2021$ by author(s) and Scientific Research Publishing Inc. This work is licensed under the Creative Commons Attribution International License (CC BY 4.0).

http://creativecommons.org/licenses/by/4.0/ (c) (i) Open Access

\begin{abstract}
Cyanobacteria may adversely impact aquatic ecosystems through oxygen depletion and cyanotoxin production. These cyanotoxins can also harm human health and livestock. In recent years, cyanobacterial blooms have been observed in several drinking water reservoirs in Kentucky, United States. In Kentucky, the paradigm is that phosphorous is the limiting nutrient for cyanobacteria growth. To explore this paradigm, an indoor microcosm study was conducted using hypereutrophic Guist Creek Lake water. Samples were collected and spiked with various combinations of locally used agricultural grade fertilizers, including ammonium nitrate, urea, and triple phosphate (calcium dihydrogen phosphate). Samples were incubated indoors for the photoperiodspecific to the time of the year. Cyanobacteria density, measured by phycocyanin, did not demonstrate increased growth with the addition of phosphate fertilizer alone. Cyanobacteria growth was enhanced in these conditions by the combined addition of ammonium nitrate, urea, and phosphorus fertilizer. Growth also occurred when using either ammonium nitrate or urea fertilizer with no additional phosphorus input, suggesting that phosphorus was not limiting the cyanobacteria at the time of sample collection. The addition of both nitrogen fertilizers (ammonium nitrate and urea) at the concentrations used in this study, in the absence of phosphorus, was deleterious to both the Chlorophyta and cyanobacteria. The results suggest further studies using more robust experimental designs are needed to explore lake-specific dual nutrient management strategies for preventing cyanobacterial blooms in this phosphorus-rich hypereutrophic lake and possibly other hypereutrophic lakes.
\end{abstract}

\section{Keywords}

Nutrient Limitation, Eutrophication, Harmful Algal Bloom, Fertilization, 
Primary Productivity, Phosphorous Loading, Nitrate Loading, Cyanobacteria Bloom

\section{Introduction}

Cyanobacterial blooms in aquatic ecosystems are known to periodically produce harmful toxins [1] [2]. Furthermore, cyanobacterial blooms have resulted in harm to fisheries through depleting dissolved oxygen [3]. Cyanobacteria impacts on lakes worldwide have been described, including in North America's Lake Erie, China's Lake Taihu, and Europe's Baltic Sea [4] [5] [6]. Small human-made freshwater lakes (reservoirs) are also frequently impacted by cyanobacteria growth as such lakes are readily impacted by surface runoff and more rapid temperature changes [7]. Beyond having their fisheries impacted, lakes (large and small) may have their local communities adversely effected from blooms due to decreased recreation and tourism, increased drinking water treatment costs, lower property values, lower quality of life, and environmental stigma [8] [9] [10].

Understanding major drivers of local water quality remains important in the midst of a changing global climate with often-greater effects on regional climates [11]. Increases in cyanobacteria bloom occurrence were predicted globally in the early 2000s [12] [13], and blooms have been reported to be occurring more frequently due to the competitive advantage cyanobacteria have over green algae (Chlorophyta) in systems experiencing more rapid eutrophication, changing nutrient inputs [14], warmer aquatic temperatures, and greater $\mathrm{CO}_{2}$ concentrations [15] [16] [17]. Recent national assessments of cyanobacteria bloom formation implicate both nitrogen and phosphorus as major drivers of US freshwater blooms [18] [19].

Greater understanding of nutrient dynamics and bloom formation drivers are needed in hypereutrophic lakes in the Upper South and Midwestern United States where these lakes provide multiple benefits including recreation and source water for drinking water utilities. During 2013 and 2014, active monitoring for cyanobacteria by the Commonwealth of Kentucky's Division of Water resulted in several lakes having cyanobacteria advisories put in place. Guist Creek Lake was the most frequently imperiled lake during the monitoring period. The cause of the bloom, like many blooms, was presumed to be from nutrient over-enrichment. More specifically though, is a need to better understand nutrient dynamics in this region (and worldwide) for mitigating cyanobacteria bloom formation [20]. The goal of this study was to explore the role of nitrogen (N) in driving late-Spring season bloom formation in this region and to assess the feasibility of a microcosm approach for modeling potential future bloom scenarios for reservoirs in Kentucky. In this study, agricultural fertilizers were added (ammonium nitrate, urea, calcium dihydrogen phosphate [triple-phosphate], and all possible combinations) to aliquots of lake water. These spiked samples were incubated in 
the laboratory, and then assessed for cyanobacteria growth.

\section{Materials and Methods}

\subsection{Sample Collection \& Study Lake}

On 09 June 2017 at 09:20, surface water samples were collected from the Guist Creek Marina $\left(38.20810^{\circ}, 85.15720^{\circ}\right)$ in ten $1 \mathrm{~L}$ glass containers for treatment in the laboratory. Guist Creek Lake is a human-made reservoir that was created from impounding Guist Creek in 1961. Guist Creek Lake is $1.3 \mathrm{~km}^{2}$ in area with $43 \mathrm{~km}$ of shoreline and is located in Shelby County, Kentucky, USA [21]. The lake is owned by the Kentucky Department of Fish and Wildlife Resources and the mean and maximum depths are $5 \mathrm{~m}$ and $14 \mathrm{~m}$, respectively [21]. Guist Creek Lake is part of the Salt River and Ohio River Basins and has been the subject of toxic algae advisories in recent years. On 01 August 2014, the Kentucky Division of Water declared an advisory for Guist Creek Lake, in addition to three other Kentucky lakes. The Shelbyville Water and Sewer Commission was drawing drinking water from Guist Creek Lake at the time of this study (partnerships with the Louisville Water Company have since been established). Guist Creek Lake is just one of several Kentucky reservoirs that has had water drawn while having had toxic cyanobacteria advisories in recent history. Guist Creek Lake also has fish consumption guidelines in place for mercury. The lake and main tributary (Guist Creek) are on the Commonwealth of Kentucky's impaired waters list as reported to Congress via Section 303(d) of the Clean Water Act. The 303(d) report indicates that nutrients and eutrophication are the cause for impairment in the lake and creek.

Guist Creek Lake drains a substantial portion of Shelby County, which is mostly pastureland (50.6\%) with a mixture of deciduous forest $(26.7 \%)$, cultivated crops (11.6\%), developed open space (4.6\%), and several other less frequent land uses (6.5\%). Land use data were obtained from the National Land Cover Database [22] [23]. The lake and catchment are in the Bluegrass region of Kentucky which has naturally occurring high phosphorus levels in both the water and soil as part of the high limestone content associated with the unique geology [24].

\subsection{Microcosm Nutrient Bioassays}

Ten $1 \mathrm{~L}$ samples were collected at Guist Creek Lake and were transported immediately to Eastern Kentucky University in coolers, where they were further equally distributed into eight glass jars of $900 \mathrm{ml}$ of water in the environmental health laboratory within 90 minutes of collection. In total, seven water samples were spiked with one or more of the following treatment substances: $3.0 \mathrm{mg}$ of triple phosphate, $\mathrm{Ca}\left(\mathrm{H}_{2} \mathrm{PO}_{4}\right),(0-45-0) ; 3.0 \mathrm{mg}$ of ammonium nitrate, $\mathrm{NH}_{4} \mathrm{NO}_{3}$ (34-0-0); and/or $3.0 \mathrm{mg}$ of urea, $\mathrm{CO}\left(\mathrm{NH}_{2}\right)_{2},(46-0-0)$. The control sample received no treatment. In total, all possible combinations were created using the same additions of nutrients. The treatment receiving the greatest amount of in- 
put was the triple phosphate $\left(\mathrm{Ca}\left(\mathrm{H}_{2} \mathrm{PO}_{4}\right)+\right.$ ammonium nitrate + urea treatment, which received $3.0 \mathrm{mg}$ of each. The treatment fertilizers were acquired from an area farm supply store. The decision to add fertilizer used (and obtained) from within the region for spiking into sample water was informed by a 2017 study in Kentucky [25].

Upon adding nutrients, magnetic stirrers were used on a slow setting for 150 minutes to ensure adequate mixing and dissolving of fertilizer into the lake sample treatments. In addition, two 24-hour electrical timers were set to turn on four (4) $250 \mathrm{v} 660 \mathrm{w}$ glow lamps at 06:30 am and to turn these lamps off at 21:10, daily, to simulate natural sunrise and sunset. Each lamp was positioned approximately $63 \mathrm{~cm}$ above the open containers. Light intensity was not measured. Container lids were not used, and glass containers were used to hold the lake water to maximize light entry thereby better mimicking the natural lake water environment. The simulated daytime temperature of approximately $30^{\circ} \mathrm{C}$ in the sample water was maintained by the generally warm summer building temperatures at the university and the glow lamps. Before all analyses, samples were gently stirred for 30 min on Day 3, Day 6, and Day 7.

\subsection{Laboratory Assessments}

An initial assessment of water quality before nutrient addition was conducted on 09 June 2017. An assessment of phycocyanin pigment and in vivo chlorophyll a was obtained on 12 June 2017. A final assessment of all water quality parameters was performed on 15 June 2017. Total phosphorus $\left(\mathrm{PO}_{4}^{3-}\right)$, total nitrate $\left(\mathrm{NO}_{3}-\mathrm{N}\right)$, and nitrogen-ammonia + ammonium $\left(\mathrm{NH}_{3}-\mathrm{N}\right)$ concentrations were determined with a Hach DR 2800 spectrophotometer using Hach Method TNT 843 (acid persulfate digestion), Hach Method 8171 (Cd reduction method), and Hach Method 8038 (Nessler reagent method), respectively. Turbidity was determined using a Lutron TU-2016 turbidimeter. Phycocyanin and in vivo chlorophyll a were determined from 0.2 aliquots of sample water placed into individual PCR tubes. The relative fluorescence units were then read by a handheld Beagle Biosciences dual-channel fluorometer (manufactured by AmiScience, Fremont, California) and compared against a standard curve. No extracted chlorophyll a concentrations were determined. Phycocyanin fluorometry has been used in studies of freshwater lakes as a specific indicator of cyanobacteria biovolume as well as harmful cyanobacteria bloom risk [26] [27] [28].

\section{Results and Discussion}

\subsection{Results}

The initial mean total phosphorus level $\left(0.27 \mathrm{mg} \cdot \mathrm{L}^{-1}\right)$ for Guist Creek Lake was hypereutrophic according to Carlson's Trophic State Index [29]. Table 1 demonstrates that phosphorus levels on the final day (Day 7) fell below quantification for the total phosphorus method used in this study $\left(<0.15 \mathrm{mg} \cdot \mathrm{L}^{-1}\right)$ in treatments not receiving the phosphorus fertilizer treatment. In treatments with 
Table 1. Initial and $7^{\text {th }}$ day nutrient concentrations and theoretical N:P ratios across seven bioassay containers receiving fertilizer treatments (ammonium nitrate, calcium dihydrogen phosphate, urea, and combinations) and one bioassay receiving no treatment.

\begin{tabular}{|c|c|c|c|c|c|c|}
\hline Treatment & $\mathrm{PO}_{4}^{3-}$ & $\mathrm{NO}_{3}-\mathrm{N}$ & $\mathrm{NH}_{3}-\mathrm{N}$ & $\mathrm{NO}_{3}-\mathrm{N}+\mathrm{NH}_{3}-\mathrm{N}$ & Mol. Ratio ${ }^{\mathrm{a}}$ & Mol. Ratio ${ }^{\mathrm{b}}$ \\
\hline Name & $\left(\mathrm{mg} \cdot \mathrm{L}^{-1}\right)$ & $\left(\mathrm{mg} \cdot \mathrm{L}^{-1}\right)$ & $\left(\mathrm{mg} \cdot \mathrm{L}^{-1}\right)$ & $\left(\mathrm{mg} \cdot \mathrm{L}^{-1}\right)$ & w/o $\mathrm{NH}_{3}-\mathrm{N}$ & $\mathrm{w} / \mathrm{NH}_{3}-\mathrm{N}$ \\
\hline \multicolumn{7}{|l|}{ Final Study Day (Day 7) } \\
\hline No Treatment & $<0.15$ & 0.80 & 0.30 & 1.10 & $>8.17$ & $>19.35$ \\
\hline $\mathrm{NH}_{4} \mathrm{NO}_{3}$ & $<0.15$ & 0.75 & 0.46 & 1.21 & $>7.66$ & $>24.80$ \\
\hline $\mathrm{CO}\left(\mathrm{NH}_{2}\right)_{2}$ & $<0.15$ & 0.90 & 0.31 & 1.21 & $>9.19$ & $>20.74$ \\
\hline $\mathrm{Ca}\left(\mathrm{H}_{2} \mathrm{PO}_{4}\right)$ & 1.81 & 0.50 & 0.37 & 0.87 & 0.42 & 1.56 \\
\hline $\mathrm{NH}_{4} \mathrm{NO}_{3}+\mathrm{CO}\left(\mathrm{NH}_{2}\right)_{2}$ & $<0.15$ & 0.80 & 0.53 & 1.33 & $>8.2$ & $>27.92$ \\
\hline $\mathrm{NH}_{4} \mathrm{NO}_{3}+\mathrm{Ca}\left(\mathrm{H}_{2} \mathrm{PO}_{4}\right)$ & 1.94 & 1.10 & 0.44 & 1.54 & 0.86 & 2.13 \\
\hline $\mathrm{CO}\left(\mathrm{NH}_{2}\right)_{2}+\mathrm{Ca}\left(\mathrm{H}_{2} \mathrm{PO}_{4}\right)$ & 1.32 & 0.60 & 0.43 & 1.03 & 0.69 & 2.52 \\
\hline $\mathrm{NH}_{4} \mathrm{NO}_{3}+\mathrm{CO}\left(\mathrm{NH}_{2}\right)_{2}+\mathrm{Ca}\left(\mathrm{H}_{2} \mathrm{PO}_{4}\right)$ & 1.09 & 1.20 & 0.44 & 1.64 & 1.69 & 3.94 \\
\hline \multicolumn{7}{|l|}{ Initial Sample (Day 0) } \\
\hline No Treatment & 0.27 & 4.20 & 0.30 & 4.50 & 23.84 & 30.04 \\
\hline
\end{tabular}

${ }^{a} \mathrm{NO}_{3}-\mathrm{N}: \quad \mathrm{PO}_{4}^{3--} \quad$ Molar Ratio; ${ }^{\mathrm{b}}\left(\mathrm{NO}_{3}-\mathrm{N}+\mathrm{NH}_{3}-\mathrm{N}\right): \quad \mathrm{PO}_{4}^{3-} \quad$ Molar Ratio.

phosphorus fertilizer, phosphorus levels remained $4.0-6.7 \mathrm{x}$ greater than the pre-existing hypereutrophic levels. T-testing demonstrated that nitrate levels in all groups, including ammonium nitrate-treated and urea-treated bioassays, were significantly lower $(\mathrm{p}<0.05)$ at Day 7 than the initial nitrate level of 4.20 $\mathrm{mg} \cdot \mathrm{L}^{-1}$ (Table 1). Ammonia + ammonium $\left(\mathrm{NH}_{3}-\mathrm{N}\right)$ levels remained at or above initial levels $\left(0.30 \mathrm{mg} \cdot \mathrm{L}^{-1}\right)$ in all treatments at Day 7 , with the highest level $(0.53$ $\mathrm{mg} \cdot \mathrm{L}^{-1}$ ) being observed in the ammonium nitrate + urea treatment.

The initial water (Day 0) was as turbid or more turbid than all treatment groups (Table 2). The most turbid treatment groups were the groups with the highest phycocyanin and chlorophyll a results (Figure 1, Figure 2). The phycocyanin (PC) results suggest cyanobacteria growth was at first nitrogen-limited as the ammonium-nitrate treatment resulted in the highest PC value on day 3 among the single nutrient treatments (Figure 1). Similarly, the other nitrogen treatment with urea produced a greater PC value on day 3 than the phosphorus fertilizer treatment. These results were not however reflected in the chlorophyll a results (Figure 2); whereby individual nitrogen and phosphorus additions had only a slight impact on chlorophyll a compared to the no treatment control, which declined. In tandem, $\mathrm{P}+\mathrm{N}$, resulted in noticeable increases in chlorophyll a relative to single nutrient treatments and the no treatment bioassay (Figure 2).

\subsection{Discussion}

Nitrogen and phosphorous enter lakes through several routes including runoff, air deposition, and rainfall. Nitrogen sources can enter water systems at relatively high concentrations directly or indirectly from fertilizers, industrial waste, and 
Table 2. $\mathrm{pH}$, electrical conductivity, and turbidity levels across seven bioassay containers receiving various fertilizer treatments (ammonium nitrate, calcium dihydrogen phosphate, urea, and combinations) and one bioassay container receiving no treatment.

\begin{tabular}{cccc}
\hline Treatment & & Sp. Cond. & Turbidity \\
\hline Group & $\mathrm{pH}$ & $\left(\mu \mathrm{S} / \mathrm{cm}^{-1}\right)$ & $(\mathrm{NTU})$ \\
\hline Final Study Day (Day 7) & & & \\
No Treatment & 8.4 & 310 & 5.90 \\
$\mathrm{NH}_{4} \mathrm{NO}_{3}$ & 8.2 & 300 & 7.16 \\
$\mathrm{CO}\left(\mathrm{NH}_{2}\right)_{2}$ & 8.7 & 290 & 2.02 \\
$\mathrm{Ca}\left(\mathrm{H}_{2} \mathrm{PO}_{4}\right)$ & 8.5 & 310 & 3.40 \\
$\mathrm{NH}_{4} \mathrm{NO}_{3}+\mathrm{CO}\left(\mathrm{NH}_{2}\right)_{2}$ & 8.5 & 300 & 4.23 \\
$\mathrm{NH}_{4} \mathrm{NO}_{3}+\mathrm{Ca}\left(\mathrm{H}_{2} \mathrm{PO}_{4}\right)$ & 8.7 & 310 & 6.75 \\
$\mathrm{CO}\left(\mathrm{NH}_{2}\right)_{2}+\mathrm{Ca}\left(\mathrm{H}_{2} \mathrm{PO}_{4}\right)$ & 8.7 & 310 & 7.59 \\
$\left.\mathrm{NH}_{4} \mathrm{NO}_{3}+\mathrm{CO}\left(\mathrm{NH}_{2}\right)_{2}+\mathrm{Ca}_{2} \mathrm{H}_{2} \mathrm{PO}_{4}\right)$ & 8.5 & 290 & 7.85 \\
Final Study Day $(\mathrm{Day} 7)$ & & & \\
$\mathrm{No}$ Treatment & 8.1 & 260 & 7.90 \\
\hline
\end{tabular}

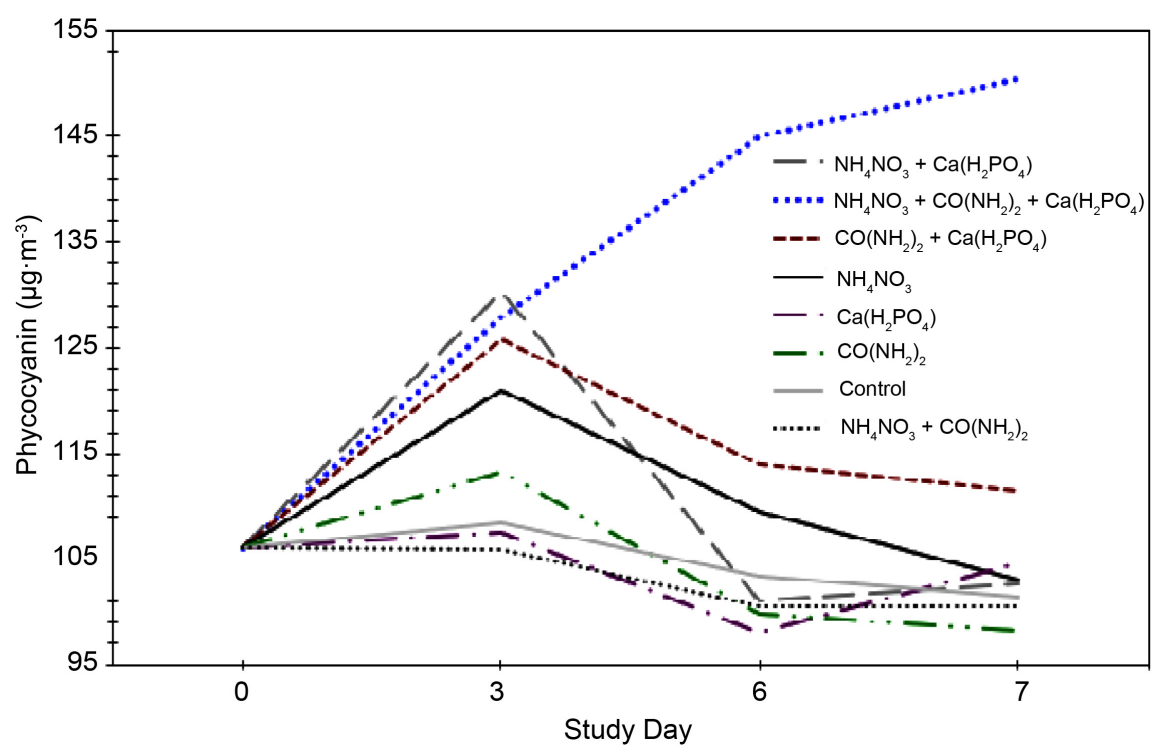

Figure 1. Phycocyanin concentrations observed in samples of bioassay containers receiving various fertilizer treatments and one bioassay container receiving no treatment.

sewage. In areas of Kentucky where phosphorus levels are naturally high [24], nitrogen fertilizers are more often used by agriculture and can enter surface water and groundwater. In the southern US, a secondary N-limitation has been described [30] for primary productivity making runoff from these $\mathrm{N}$-sources noteworthy for investigation. By comparing Carlson's Trophic State Index [29] for total phosphorus with Kratzer and Brezonik's Index for nitrate [30] we see higher expected primary productivity with total phosphorus $(\mathrm{TSI}=84.9$; very hypereutrophic) compared to total nitrate (TSI $=75.2$; hypereutrophic). For this study, we used in vivo chlorophyll a for calculating Carlson's TSI for chlorophyll $a$. 


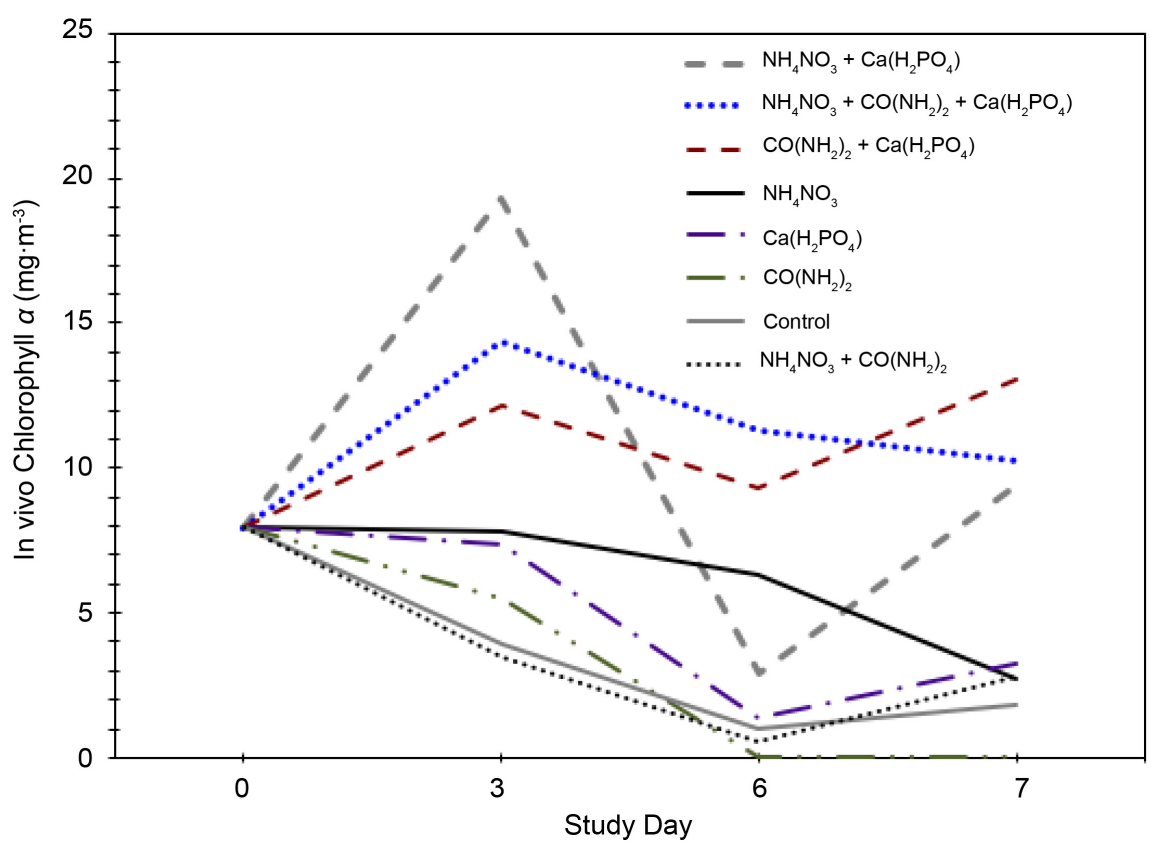

Figure 2. In vivo chlorophyll a concentrations determined directly from water from bioassay containers receiving various fertilizer treatments or no treatment.

Here, we observed lower chlorophyll a values than expected by the TSI values for either total phosphorus and nitrate. Carlson's TSI [29] for chlorophyll a using the non-extracted value recorded here produced a TSI of 51 (mildly eutrophic) in the initial untreated water. If chlorophyll a levels were doubled by extraction, the TSI would increase to 58 (eutrophic), but still be lower than expected by both the TSI values for $\mathrm{P}$ and N. This pattern is not unique in Kentucky, as Reeder [25] observed a similar trend in Eastern Kentucky Lakes $\left(\mathrm{TSI}_{\mathrm{TP}}>\mathrm{TSI}_{\text {Nitrate }}>\right.$ TSI $_{\text {chla }}$ ). One possible reason for this discrepancy in summer TSI values is that turbidity is presumed to cause light limitations in many Kentucky lakes [25].

In an effort to identify a nutrient pattern associated with cyanobacteria bloom production at Guist Creek Lake, a secondary N-limitation was artificially created in this study, following a massive infusion of total phosphorus $\left(>3 \mathrm{mg} \cdot \mathrm{L}^{-1}\right)$ in several of the treatments. Furthermore, artificially low N:P ratios were then simultaneously created, which presumably favored the growth of N-fixing cyanobacteria and low N:P tolerant Microcystis [31] [32]. Such a scenario (or a milder version) could potentially play out following heavy rainfall in many of Kentucky's agricultural watersheds. The chemical composition of nitrogen fertilizers used throughout the United States is gradually shifting to urea in lieu of ammonium nitrate. In fact, almost $90 \%$ of nitrogen fertilizers are now composed of urea [20]. In this study, urea, like ammonium nitrate, was also capable of stimulating cyanobacterial growth (and potentially bloom formation). This study provides evidence for future studies on nutrient dynamics related to blooms of unknown origin to consider monitoring urea, which is often not included (or measured) in most water quality analyses [20], including this study. 
Figure 1 demonstrated that both, urea and ammonium nitrate, increased cyanobacterial growth more than phosphorus fertilizer alone at Guist Creek Lake. Ultimately, either urea or ammonium nitrate were able to facilitate cyanobacterial growth when phosphorus was already abundant; thereby making nitrogen instrumental in facilitating cyanobacterial blooms in this lake as observed in other hypereutrophic lakes [14] [33]. Given the relationship between TSI values reported here and elsewhere in Kentucky [25], the impact of nitrogen on cyanobacteria bloom potential and formation throughout Kentucky and beyond warrants greater investigation and potential changes in nutrient management policies.

\subsection{Relationship to Recent Studies}

Since the 1970s, freshwater ecologists have frequently recognized the importance of available phosphorous as a limiting factor for inland freshwater productivity [34]. There has been an assumption in Kentucky that a reduction in phosphorous inputs would reduce harmful cyanobacterial blooms, essentially treating cyanobacteria similar to chlorophytes. For shallow, smaller hypereutrophic lakes with $\mathrm{P}$ loaded sediments, greater attention may be needed towards nitrogen management. Guist Creek Lake is $1.3 \mathrm{~km}^{2}$ with a $5 \mathrm{~m}$ mean depth and would be described as a small shallow lake. Recent research examining 573 lakes observed nitrogen limitations (and nitrogen-phosphorus co-limitations) frequently in shallow lakes, with the nitrogen limitation being even more likely as the trophic status increases [35]. The initial sample from Guist Creek Lake had a very high trophic status index value of 84.9 based upon total phosphorus, suggesting Guist Creek Lake could experience nitrogen limitations that favor cyanobacteria dominance like other small shallow lakes globally [35].

For evaluation of the plausibility of the scenario presented in this study, recent 2020 study results from several mesocosm studies done on Wascana Lake can be explored. Specifically, the small lake located in Saskatchewan, Canada is also shallow (7.5 m maximum depth), small $\left(0.5 \mathrm{~km}^{2}\right)$, and hypereutrophic with similar phosphorus concentrations as observed in Guist Creek Lake. As nitrogen loading occurred in Wascana Lake, particularly urea, cyanobacteria dominance increased along with cyanotoxin concentrations until reaching and exceeding a potentially toxic nitrogen level [36].

Beyond small lakes, even larger lakes, such as Lake Erie, notably the western basin, have been recently linked to having cyanobacteria blooms attributable to nitrogen limitations and/or nitrogen-phosphorus co-limitations [37]. The bioassay study on Guist Creek Lake has a number of research limitations but does provide evidence of the potential need for nitrogen (or dual nutrient) management strategies being implemented in the watershed of Guist Creek if bloom conditions are to be prevented. Cyanobacteria research experts recommend mitigating the adverse impact of harmful bloom events and suggest the single nutrient reduction paradigm for freshwater be replaced by a dual nutrient $(\mathrm{N}$ and 
P) reduction paradigm better suited for the current rapidly changing global climate and existing terrestrial and aquatic nutrient loads [38]. Extending beyond benefits to freshwater lakes, nitrogen reductions have been long-established as being essential in the United States for mitigating hypoxia and harmful algal bloom events in the Gulf of Mexico [39] [40]. As rainfall continues to increase across the US, modifications to existing fertilizer application approaches are recommended to diminish the adverse impacts of nitrogen on the Gulf of Mexico [41] and many productive lakes (small and large) as part of a dual nutrient management strategy [20] [38] [42].

\subsection{Study Limitations}

\subsubsection{Carbon Impacts Not Assessed}

The microcosm approach as used is limited for a number of reasons worthy of consideration for interpretation of results as well as the design of similar or future studies. Firstly, natural succession could not occur in this simulated setting. Although the samples were not entirely closed systems as they did have access to atmospheric air including nitrogen and $\mathrm{CO}_{2}$, carbon supplementation was not provided nor was a carbon-limitation directly assessed. Elevated cyanobacteria density, including cyanobacterial bloom events, can create carbon limitations whereby $\mathrm{CO}_{2}$ (the carbon source) is intercepted at the surface by surface cyanobacteria, which is advantageous for bloom-forming surface cyanobacteria relative to other phytoplankton [43]. Furthermore, carbon utilization from $\mathrm{CO}_{2}$, especially when carbon is less available below the surface, may favor certain cyanobacteria species and even strains within those species relative to other phytoplankton [44]. In this study, which provided more nutrients to an existing hypereutrophic lake, the only input of carbon was atmospheric for all the samples with the exception of the urea treated containers. Given the lack of turbulence in samples reducing the amount of $\mathrm{CO}_{2}$ along with a presumed cyanobacteria population, the carbon limitation may explain why phytoplankton densities increased in treated samples but then declined after day 3 , and in some cases, the decline was more than observed in the control.

In the treatment receiving phosphorus in the form of $\mathrm{Ca}\left(\mathrm{H}_{2} \mathrm{PO}_{4}\right)$ along with ammonium nitrate $\left(\mathrm{NH}_{4} \mathrm{NO}_{3}\right)$ and urea $\left(\mathrm{CO}\left(\mathrm{NH}_{2}\right)_{2}\right)$, cyanobacteria density was not only the highest among other samples on Day 3, but the cyanobacterial bloom continued to increase throughout the entire seven-day period (Figure 1). Although speculative, it is plausible that in this one treatment receiving the three fertilizers, the urea acted as both a carbon and nitrogen source for cyanobacteria during the bloom conditions, which has been observed with Microcystis during dense bloom conditions [45].

Future studies providing frequent observations of $\mathrm{pH}$, alkalinity, and other parameters would be needed to explore this speculation that a carbon limitation was present and impacting growth in the other samples. The ability to tolerate carbon-limited conditions has been linked to cyanobacteria dominance in hypereutrophic conditions [46], and the results from this study demonstrate that a 
more complicated study design that includes carbon would be needed to better understand cyanobacterial bloom dynamics in Guist Creek Lake under the study conditions that were created.

\subsubsection{Spiked Phosphorus Concentrations and Phosphorus Measurement}

The phosphorus concentrations in the phosphorus-spiked treatments exceeded $1.0 \mathrm{mg} \cdot \mathrm{L}^{-1}$ throughout the duration of the study. The total phosphorus concentrations that exceeded $1.0 \mathrm{mg} \cdot \mathrm{L}^{-1}$ ranged from $1.09 \mathrm{mg} \cdot \mathrm{L}^{-1}$ to $1.94 \mathrm{mg} \cdot \mathrm{L}^{-1}$. The phosphorus concentrations created in this study are not likely (or would be extreme) in Guist Creek Lake or other natural lakes and reservoirs. Among 727 lakes evaluated in this ecoregion of the United States, the maximum observed total phosphorus concentration reported in the US Environmental Protection Agency's data sets from 1990 to 1998 was $1.15 \mathrm{mg} \cdot \mathrm{L}^{-1}$ [47]. In the well-studied hypereutrophic Lake Taihu, China, over two years, the maximum total phosphorus concentrations for each year were $0.250 \mathrm{mg} \cdot \mathrm{L}^{-1}$ and $0.737 \mathrm{mg} \cdot \mathrm{L}^{-1}$ [48]. Future studies should create phosphorus solutions with concentrations within more applicable ranges.

Additionally, noticeable reductions in phosphorus occurred in this study from the starting concentration of $0.27 \mathrm{mg} \cdot \mathrm{L}^{-1}$ in the untreated sample. The reductions to concentrations below $0.15 \mathrm{mg} \cdot \mathrm{L}^{-1}$ in several treatments demonstrated utilization, but better quantification techniques would be needed for further exploring if a P-limitation was fully realized and for better utilizing and understanding the N:P ratios created in this study. Specifically, the detection limit of Hach TNT method 843 was $0.15 \mathrm{mg} \cdot \mathrm{L}^{-1}$ and given the low sensitivity of the method, several samples were not able to be quantified. Methods obtaining results at lower ranges would be beneficial for similar studies.

\subsubsection{Ammonia and Potential Ammonia Toxicity}

An additional consideration not adequately addressed by this study design relates to the potential for ammonia toxicity. The ammonia + ammonium concentrations were $0.53 \mathrm{mg} \cdot \mathrm{L}^{-1}$ at the end of the study in the treatment receiving ammonium nitrate and urea, which was the highest ammonia + ammonium concentration observed. Additionally, this treatment group had less chlorophyll a and phycocyanin relative to the control at the end of the study and relative to the control at the study start. It is plausible ammonia toxicity existed, and it is known that ammonia concentrations can influence grazing zooplankton populations [49] as well as phytoplankton including cyanobacteria [36] [50]. More frequent monitoring of ammonia levels would be required to observe if there were spike(s) in ammonia, and if these spikes were able to shift species composition.

\subsubsection{Limitations of a Relatively Closed System Study}

Overall, the bioassay containers were closed systems in that the recruitment of new cyanobacteria, chlorophytes, zooplankton, autochthonous lake nutrients, 
and cyanophages was not possible from outside the initial sample. The nutrient additions, even in closed conditions, could have shifted species dominance [25]. In addition, wave action and general turbulence were essentially removed entirely, thereby enabling turbidity to be unnaturally reduced which promoted greater photosynthesis by both cyanobacteria and green algae exposed to a constant diurnal light source. Furthermore, in hypereutrophic lakes, the phosphorus in lower levels of the lake and in the sediments can be mobile, with even significant phosphorus gradients existing within the upper 10 to $20 \mathrm{~cm}$ of the lake surface [51]. Given the lake may not have fully stratified prior to samples being collected for this study, phosphorus, among other nutrients would have likely been mobile in the true lake system.

\section{Conclusion}

Nutrient management strategies aimed at only addressing one nutrient may be successful in some lakes, but in the case of Guist Creek Lake (and potentially other eutrophic and hypereutrophic Kentucky Lakes), certain cyanobacteria, including bloom formers, may become more dominant due to $\mathrm{N}$ availability and a $\mathrm{N}: \mathrm{P}$ ratio that favors their dominance. This study demonstrates and reaffirms the need in Kentucky for "knowing your lake", employing dual nutrient management strategies for phosphorous and nitrogen, and considering the complex interactions extending beyond phosphorus-alone mitigation strategies for limiting the production or dominance of cyanobacteria. Future field studies, including monitoring studies, and possibly more controlled experimental designs within the range of ecological plausibility, are needed to confirm these findings for Guist Creek Lake. Furthermore, these results add to the evidence that nitrogen sources and/or N:P ratios may modulate cyanobacteria growth in existing P-loaded shallow and small hypereutrophic lakes.

\section{Acknowledgements}

The data collection and experimental design of this research occurred without any specific funding and utilized existing laboratory resources. Manuscript writing support was partially supported by a 2019 US Geological Survey (USGS) 104(b) Student Research Enhancement Grant award via the Kentucky Water Resources Research Institute (KWRRI). Dissemination support was provided by a Research Enhancement Grant from the Office of Sponsored Programs at Eastern Kentucky University. The authors are grateful for the support of the Master of Public Health Program and the Environmental Health Science Departmental faculty at Eastern Kentucky University.

\section{Conflicts of Interest}

The authors declare no conflicts of interest regarding the publication of this paper. 


\section{References}

[1] Carmichael, W.W. and Boyer, G.L. (2016) Health Impacts from Cyanobacteria Harmful algae Blooms: Implications for the North American Great Lakes. Harmful Algae, 54, 194-212. https://doi.org/10.1016/j.hal.2016.02.002

[2] Brooks, B.W., Lazorchak, J.M., Howard, M.D., Johnson, M.V.V., Morton, S.L., Perkins, D.A., Reavie, E.D., Scott, G.I., Smith, S.A. and Steevens, J.A. (2016) Are Harmful Algal Blooms Becoming the Greatest Inland Water Quality Threat to Public Health and Aquatic Ecosystems? Environmental Toxicology and Chemistry, 35, 6-13. https://doi.org/10.1002/etc.3220

[3] Scavia, D., Allan, J.D., Arend, K.K., Bartell, S., Beletsky, D., Bosch, N.S., Brandt, S.B., Briland, R.D., Daloğlu, I., DePinto, J.V. and Dolan, D.M. (2014) Assessing and Addressing the Re-Eutrophication of Lake Erie: Central Basin Hypoxia. Journal of Great Lakes Research, 40, 226-246. https://doi.org/10.1016/j.jglr.2014.02.004

[4] Steffen M.M, Belisle B.S., Watson S.B., Boyer G.L. and Wilhelm S.W. (2014) Status, Causes and Controls of Cyanobacterial Blooms in Lake Erie. Journal of Great Lakes Research, 40, 215-225. https://doi.org/10.1016/j.jglr.2013.12.012

[5] Guo L. (2007) Doing Battle with the Green Monster of Taihu Lake. Science, 317, 1166. https://doi.org/10.1126/science.317.5842.1166

[6] Wulff F., Savchuk O.P., Sokolov A., Humborg C. and Mörth C.M. (2007) Management Options and Effects on a Marine Ecosystem: Assessing the Future of the Baltic. AMBIO: A Journal of the Human Environment, 36, 243-249. https://doi.org/10.1579/0044-7447(2007)36[243:MOAEOA]2.0.CO;2

[7] Gorham, T., Jia, Y., Shum, C.K. and Lee, J. (2017) Ten-Year Survey of Cyanobacterial Blooms in Ohio's Waterbodies Using Satellite Remote Sensing. Harmful Algae, 66, 13-19. https://doi.org/10.1016/j.hal.2017.04.013

[8] Carmichael, W. (2008) A World Overview-One-Hundred-Twenty-Seven Years of Research on Toxic Cyanobacteria-Where Do We Go from Here? In: Hudnell, H.K., Ed., Cyanobacterial Harmful Algal Blooms. State of the Science and Research Needs, New York, Springer, 105-125. https://doi.org/10.1007/978-0-387-75865-7 4

[9] Cunha, D.G.F., Sabogal-Paz, L.P. and Dodds, W.K. (2016) Land Use Influence on Raw Surface Water Quality and Treatment Costs for Drinking Supply in São Paulo State (Brazil). Ecological Engineering, 94, 516-524. https://doi.org/10.1016/j.ecoleng.2016.06.063

[10] Wolf, D. and Klaiber, H.A. (2017) Bloom and Bust: Toxic Algae's Impact on Nearby Property Values. Ecological Economics, 135, 209-221.

https://doi.org/10.1016/j.ecolecon.2016.12.007

[11] Paerl, H.W. and Paul, V.J. (2012) Climate Change: Links to Global Expansion of Harmful Cyanobacteria. Water Research, 46, 1349-1363. https://doi.org/10.1016/j.watres.2011.08.002

[12] Harvell, C.D., Kim, K., Burkholder, J.M., Colwell, R.R., Epstein, P.R., Grimes, D.J., Hoffman, E.E., Lipp, E.K., Osterhaus, A.D.M.E., Overstreet, R.M., Porter, J.W., Smith, G.W. and Vasta, G.R. (2000) Emerging Marine Diseases-Climate Links and Anthropogenic Factors. Science, 285, 1505-1510.

https://doi.org/10.1126/science.285.5433.1505

[13] Peperzak, L. (2003) Climate Change and Harmful Algal Blooms in the North Sea. Acta Oecologica, 24, S139-S144. https://doi.org/10.1016/S1146-609X(03)00009-2

[14] Paerl, H.W., Gardner, W.S., Havens, K.E., Joyner, A.R., McCarthy, M.J., Newell, S.E., Qin, B. and Scott, J.T.(2016) Mitigating Cyanobacterial Harmful Algal Blooms 
in Aquatic Ecosystems Impacted by Climate Change and Anthropogenic Nutrients. Harmful Algae, 54, 213-222. https://doi.org/10.1016/j.hal.2015.09.009

[15] Paerl, H.W. and Huisman, J. (2008) Blooms Like It Hot. Science, 320, 57-58. https://doi.org/10.1126/science.1155398

[16] Huisman, J., Codd, G.A., Paerl, H.W., Ibelings, B.W., Verspagen, J.M.H. and Visser, King, K.W., Balogh, J.C. and Harmel, R.D. (2007) Nutrient Flux in Storm Water Runoff and Baseflow from Managed Turf. Environmental Pollution, 150, 321-328. https://doi.org/10.1016/j.envpol.2007.01.038

[17] Visser, P.M., Verspagen, J.M., Sandrini, G., Stal, L.J., Matthijs, H.C., Davis, T.W., Paerl, H.W. and Huisman, J. (2016) How Rising $\mathrm{CO}_{2}$ and Global Warming May Stimulate Harmful Cyanobacterial Blooms. Harmful Algae, 54, 145-159. https://doi.org/10.1016/j.hal.2015.12.006

[18] Marion, J.W., Zhang, F., Cutting, D. and Lee, J. (2017) Associations between County-Level Land Cover Classes and Cyanobacteria Blooms in the United States. Ecological Engineering, 108, 556-563.https://doi.org/10.1016/j.ecoleng.2017.07.032

[19] Beaver, J.R., Tausz, C.E., Scotese, K.C., Pollard, A.I. and Mitchell, R.M. (2018) Environmental Factors Influencing the Quantitative Distribution of Microcystin and Common Potentially Toxigenic Cyanobacteria in US Lakes and Reservoirs. Harmful Algae, 78, 118-128. https://doi.org/10.1016/j.hal.2018.08.004

[20] Paerl, H.W., Scott, J.T., McCarthy, M.J., Newell, S.E., Gardner, W.S., Havens, K.E., Hoffman, D.K., Wilhelm, S.W. and Wurtsbaugh, W.A. (2016) It Takes Two to Tango: When and Where Dual Nutrient (N \& P) Reductions Are Needed to Protect Lakes and Downstream Ecosystems. Environmental Science and Technology, 50, 10805-10813. https://doi.org/10.1021/acs.est.6b02575

[21] Kleber, J.E. (1992) The Kentucky Encyclopedia. University Press of Kentucky, Lexington.

[22] Homer, C.G., Dewitz, J.A., Yang, L., Jin, S., Danielson, P., Xian, G., Coulston, J., Herold, N.D., Wickham, J.D. and Megown, K. (2015) Completion of the $2011 \mathrm{Na}$ tional Land Cover Database for the Conterminous United States-Representing a Decade of 668 Land Cover Change Information. Photogrammetric Engineering and Remote Sensing, 81, 345-354.

https://www.asprs.org/a/publications/pers/2015journals/PERS May 2015/HTML/fi les/assets/common/downloads/PE\&RS\%20May\%202015.pdf

[23] Fry, J.A., Xian, G., Jin, S., Dewitz, J.A., Homer, C.G., Limin, Y., Barnes, C.A., Herold, N.D. and Wickham, J.D. (2011) Completion of the 2006 National Land Cover Database for the Conterminous United States. Photogrammetric Engineering and Remote Sensing, 77, 858-864.

[24] Cressman, E.R. (1973) Lithostratigraphy and Depositional Environments of the Lexington Limestone (Ordovician) of Central Kentucky. U.S. Geological Survey Professional Paper No. 768, U.S. Geological Survey, Reston, 61 p. https://doi.org/10.3133/pp768

[25] Reeder, B.C. (2017) Primary Productivity Limitations in Relatively Low Alkalinity, High Phosphorus, Oligotrophic Kentucky Reservoirs. Ecological Engineering, 108, 477-481. https://doi.org/10.1016/j.ecoleng.2017.06.009

[26] McQuaid, N., Zamyadi, A., Prévost, M., Bird, D.F. and Dorner, S. (2011) Use of in Vivo Phycocyanin Fluorescence to Monitor Potential Microcystin-Producing Cyanobacterial Biovolume in a Drinking Water Source. Journal of Environmental Monitoring, 13, 455-463. https://doi.org/10.1039/C0EM00163E

[27] Marion, J.W., Lee, J., Wilkins III, J.R., Lemeshow, S., Lee, C., Waletzko, E.J. and 
Buckley, T.J. (2012) In Vivo Phycocyanin Fluorometry as a Potential Rapid Screening Tool for Predicting Elevated Microcystin Concentrations at Eutrophic Lakes. Environmental Science \& Technology, 46, 4523-4531. https://doi.org/10.1021/es203962u

[28] Zamyadi, A., MacLeod, S.L., Fan, Y., McQuaid, N., Dorner, S., Sauvé, S. and Prévost, M. (2012) Toxic Cyanobacterial Breakthrough and Accumulation in a Drinking Water Plant: A Monitoring and Treatment Challenge. Water Research, 46, 1511 1523. https://doi.org/10.1016/j.watres.2011.11.012

[29] Carlson, R.E. (1977). A Trophic State Index for Lakes. Limnology and Oceanography, 22, 361-369. https://doi.org/10.4319/lo.1977.22.2.0361

[30] Kratzer, C.R. and Brezonik, P.L. (1981) A Carlson-Type Trophic State Index for Nitrogen in Florida Lakes. Water Resources Bulletin, 17, 713-715. https://doi.org/10.1111/j.1752-1688.1981.tb01282.x

[31] Smith, V.H. and Schindler, D.W. (2009) Eutrophication Science: Where Do We Go from Here? Trends in Ecology and Evolution, 24, 201-207. https://doi.org/10.1016/j.tree.2008.11.009

[32] Tilman, D. (1977) Resource Competition between Plankton Algae: An Experimental and Theoretical Approach. Ecology, 58, 338-348.https://doi.org/10.2307/1935608

[33] Bui, M.H., Pham, T.L. and Dao, T.S. (2017) Prediction of Cyanobacterial Blooms in the Dau Tieng Reservoir Using an Artificial Neural Network. Marine and Freshwater Research, 68, 2070-2080. https://doi.org/10.1071/MF16327

[34] Schindler, D.W. (1977) Evolution of Phosphorus Limitation in Lakes; Natural Mechanisms Compensate for Deficiencies of Nitrogen and Carbon in Eutrophied Lakes. Science, 195, 260-262. https://doi.org/10.1126/science.195.4275.260

[35] Qin, B., Zhou, J., Elser, J.J., Gardner, W.S., Deng, J. and Brookes, J.D. (2020) Water Depth Underpins the Relative Roles and Fates of Nitrogen and Phosphorus in Lakes. Environmental Science \& Technology, 54, 3191-3198. https://doi.org/10.1021/acs.est.9b05858

[36] Bogard, M.J., Vogt, R.J., Hayes, N.M. and Leavitt, P.R. (2020) Unabated Nitrogen Pollution Favors Growth of Toxic Cyanobacteria over Chlorophytes in Most Hypereutrophic Lakes. Environmental Science \&Technology, 54, 3219-3227. https://doi.org/10.1021/acs.est.9b06299

[37] Barnard, M.A., Chaffin, J.D., Plaas, H.E., Boyer, G.L., Wei, B., Wilhelm, S.W., Rossignol, K.L., Braddy, J.S., Bullerjahn, G.S., Bridgeman, T.B. and Davis, T.W. (2021) Roles of Nutrient Limitation on Western Lake Erie CyanoHAB Toxin Production. Toxins, 13, 47. https://doi.org/10.3390/toxins13010047

[38] Paerl, H.W., Havens, K.E., Xu, H., Zhu, G., McCarthy, M.J., Newell, S.E., Scott, J.T., Hall, N.S., Otten, T.G. and Qin, B. (2020) Mitigating Eutrophication and Toxic Cyanobacterial Blooms in Large Lakes: The Evolution of a Dual Nutrient (N and P) Reduction Paradigm. Hydrobiologia, 847, 4359-4375.

https://doi.org/10.1007/s10750-019-04087-y

[39] Scavia, D., Rabalais, N.N., Turner, R.E., Justić, D. and Wiseman Jr, W.J. (2003) Predicting the Response of Gulf of Mexico Hypoxia to Variations in Mississippi River Nitrogen Load. Limnology and Oceanography, 48, 951-956. https://doi.org/10.4319/lo.2003.48.3.0951

[40] Mitsch, W.J., Day, J.W., Gilliam, J.W., Groffman, P.M., Hey, D.L., Randall, G.W. and Wang, N. (2001) Reducing Nitrogen Loading to the Gulf of Mexico from the Mississippi River Basin: Strategies to Counter a Persistent Ecological Problem: Ecotechnology-The Use of Natural Ecosystems to Solve Environmental Problems- 
Should Be a Part of Efforts to Shrink the Zone of Hypoxia in the Gulf of Mexico. BioScience, 51, 373-388. https://doi.org/10.1641/0006-3568(2001)051[0373:RNLTTG]2.0.CO;2

[41] Lu, C., Zhang, J., Tian, H., Crumpton, W.G., Helmers, M.J., Cai, W.J., Hopkinson, C.S. and Lohrenz, S.E. (2020) Increased Extreme Precipitation Challenges Nitrogen Load Management to the Gulf of Mexico. Communications Earth \& Environment, 1, Article No. 21. https://doi.org/10.1038/s43247-020-00020-7

[42] Maberly, S.C., Pitt, J.A., Davies, P.S. and Carvalho, L. (2020) Nitrogen and Phosphorus Limitation and the Management of Small Productive Lakes. Inland Waters, 10, 159-172. https://doi.org/10.1080/20442041.2020.1714384

[43] Ibelings, B.W. and Maberly, S.C. (2003) Photoinhibition and the Availability of Inorganic Carbon Restrict Photosynthesis by Surface Blooms of Cyanobacteria. Limnology and Oceanography, 43, 408-419. https://doi.org/10.4319/lo.1998.43.3.0408

[44] Sandrini, G., Ji, X., Verspagen, J.M., Tann, R.P., Slot, P.C., Luimstra, V.M., Schuurmans, J.M., Matthijs, H.C. and Huisman, J. (2016) Rapid Adaptation of Harmful Cyanobacteria to Rising CO2. Proceedings of the National Academy of Sciences of the United States of America, 113, 9315-9320.

https://doi.org/10.1073/pnas.1602435113

[45] Krausfeldt, L.E., Farmer, A.T., Castro Gonzalez, H.F., Zepernick, B.N., Campagna, S.R. and Wilhelm, S.W. (2019) Urea Is Both a Carbon and Nitrogen Source for Microcystis Aeruginosa: Tracking 13C Incorporation at Bloom pH Conditions. Frontiers in Microbiology, 10, 1064. https://doi.org/10.3389/fmicb.2019.01064

[46] Van Dam, B.R., Tobias, C., Holbach, A., Paerl, H.W. and Zhu, G. (2018) $\mathrm{CO}_{2} \mathrm{Li}-$ mited Conditions Favor Cyanobacteria in a Hypereutrophic Lake: An Empirical and Theoretical Stable Isotope Study. Limnology and Oceanography, 63, 1643-1659. https://doi.org/10.1002/lno.10798

[47] U.S. Environmental Protection Agency (2000) Ambient Water Quality Criteria Recommendations: Information Supporting the Development of State and Tribal Nutrient Criteria-Lakes and Reservoirs in Nutrient Ecoregion IX. EPA 822-B00-011.

https://www.epa.gov/nutrient-policy-data/ecoregional-nutrient-criteria-lakes-and-r eservoirs-documents

[48] Zhu, G., Wang, F., Gao, G. and Zhang, Y. (2008) Variability of Phosphorus Concentration in Large, Shallow and Eutrophic Lake Taihu, China. Water Environment Research, 80, 832-839. https://doi.org/10.2175/106143008X304749

[49] Sarma, S.S.S., Mangas-Ramírez, E. and Nandini, S. (2003) Effect of Ammonia Toxicity on the Competition among Three Species of Cladocerans (Crustacea: Cladocera). Ecotoxicology and Environmental Safety, 55, 227-235. https://doi.org/10.1016/S0147-6513(02)00120-3

[50] Dai, G.Z., Shang, J.L. and Qiu, B.S. (2012) Ammonia May Play an Important Role in the Succession of Cyanobacterial Blooms and the Distribution of Common Algal Species in Shallow Freshwater Lakes. Global Change Biology, 18, 1571-1581. https://doi.org/10.1111/j.1365-2486.2012.02638.x

[51] Søndergaard, M., Jensen, J.P. and Jeppesen, E. (2003) Role of Sediment and Internal Loading of Phosphorus in Shallow Lakes. Hydrobiologia, 506, 135-145.

https://doi.org/10.1023/B:HYDR.0000008611.12704.dd 